\title{
CUENCA (SPAIN), WORLD HERITAGE CITY. ANALYSIS OF VERNACULAR ARCHITECTURE AND MANAGEMENT STRATEGIES
}

\author{
L. García-Soriano ${ }^{1,2, *}$, V. Cristini ${ }^{1,2}$, M. Diodato ${ }^{1,2}$ \\ ${ }^{1}$ Departamento de Composición Arquitectónica, Universitat Politècnica de València, Valencia, Spain - (ligarso, madio)@ upv.es, \\ vacri@cpa.upv.es \\ ${ }^{2}$ Research Centre PEGASO, Universitat Politècnica de València, Valencia, Spain
}

Commission II - WG II/8

KEY WORDS: World Heritage Sites, Cuenca, Management strategies, Vernacular architecture, 3D Virtual analysis

\begin{abstract}
:
This text presents a study on the city of Cuenca, carried out as part of the Project 3DPast-Living \& virtual visiting European World Heritage. Nine case studies were selected within the project, when Cuenca was selected as the Spanish case study. The case studies selected had to be cases of inhabited vernacular architecture in places still preserving the traditional constructive techniques. In addition the selection was expected to cover all of Europe in some way. This is therefore a case study for a city declared World Heritage site, aiming to analyse the characteristics of vernacular architecture which have earned it the title of World Heritage Site (through different analyses and 3D methodologies), such as the management strategies currently used there, learning from those proving successful, and even showing these as an example of management for other World Heritage cities which may be encountering similar problems.
\end{abstract}

\section{INTRODUCCIÓN}

\subsection{El Proyecto 3DPast}

The 3DPast project will focus on the vernacular dwellings located in different sites across Europe. It is to explore the architectural aspects regarding the maintenance of the buildings maintenance, in order to contribute to the awareness and the preservation of the principles of authenticity and integrity at those sites.

Moreover, it will also contribute to the interpretation of the local building culture and historical evolution of the sites of the dwellings, to be recreated through $3 \mathrm{D}$ visualization and augmented reality. This could become a powerful didactic tool for children, young people and interested citizens to learn and value the relevance of the vernacular buildings to be preserved, as well as to enhance the intangible culture still in-use nowadays, relating to the buildings' architectural techniques, materials, and building system maintenance.

\subsection{Historic Walled City of Cuenca}

Cuenca, the capital of the community of Castilla-La Mancha in central Spain, is located in the middle of the deep gorges of the Júcar and Huécar rivers.

The fusion between architecture and its natural environment earned the city of Cuenca its declaration by UNESCO as World Heritage in 1996. With its privileged situation, Cuenca maintains a medieval urban distribution almost intact and for this reason was included in the World Heritage List of UNESCO as a Fortified Historic City. The city is divided into two separate areas: the "new" city southwest of the old one, separated by the Huécar river (Figure 1).

This unusually well-preserved medieval fortified city was built in a defensive position at the heart of the Caliphate of Cordoba. It was conquered by the Castilians in the 12th century, and became a royal town and bishopric endowed with important buildings, such as Spain's first Gothic cathedral, and the famous "casas colgadas" (hanging houses), hanging from sheer cliffs overlooking the Huécar river. The city towers above the magnificent countryside, taking full advantage of its location.

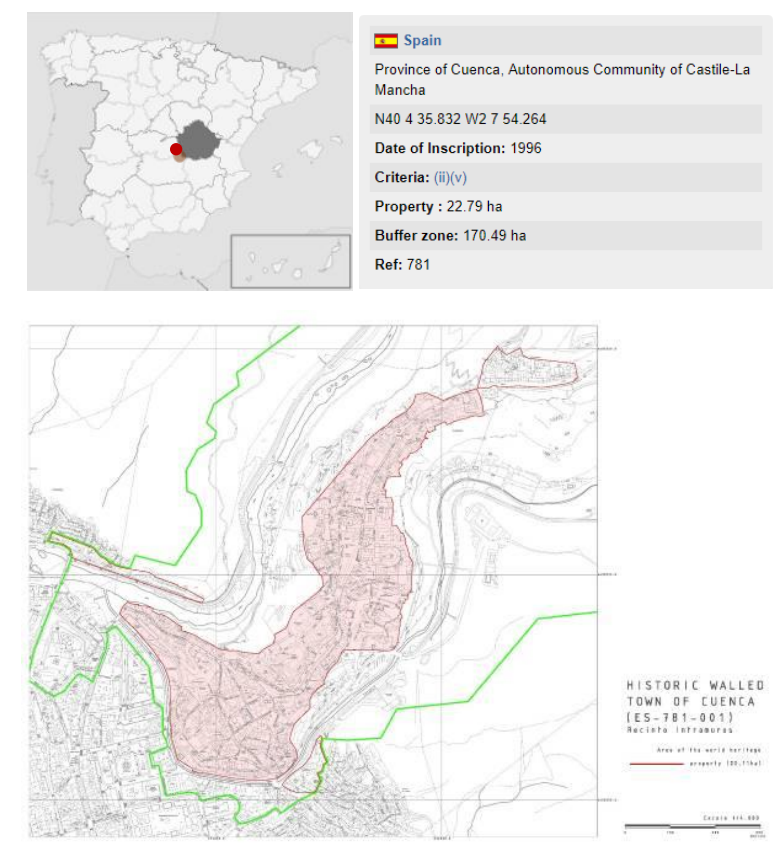

Figure 1. General data and area declared by UNESCO.

The 'Ciudad Alta' of Cuenca (the old city) is the actual object of the UNESCO recognition, and 4 different neighbourhoods can be found there. The Old Town, with its traditional architecture, streets, and passageways between houses, transmit a centuries-old way of life and, the need to adapt to the high rugged terrain by 'hanging' part of the architecture given the lack of space inside the city walls.

\footnotetext{
* Corresponding author
} 
As regards management strategies, in 2004, the Real Patronato de Cuenca, the Royal Board of the City, was created to promote and coordinate all the actions to be carried out in Cuenca by the Administrations and different entities for the promotion of the conservation and revitalization of the city's cultural heritage. This consortium has a website showing the different actions and strategies under development. (with the latest events, news...) (http://www.consorciodecuenca.es/).

Moreover, the 15 Spanish cities recognized as UNESCO World Heritage Cities have been working together for 25 years, with the aim of defending common interests, studying solutions to similar problems and promoting quality cultural, historic and artistic tourism. There are three different working commissions in this group: City and Heritage; Education and Culture; and Representation, Promotion and Tourism.

Some of the results of these groups are on the website http://www.ciudadespatrimonio.org/. It should be emphasized that these cities have issued specific publications on heritage, such as publications on the urban evolution of these cities. Other heritage publications focus on children, publishing didactic material to heighten children's awareness. This collection of small publications is highly attractive visually and aimed at young people. In the small book on Cuenca there are some pages dedicated to defining keys to heritage conservation, such as protecting, caring, getting to know about it, and sharing with others.

These publications also feature some small games and activities to make visiting the city an educational experience which is fun for children (Figure 2).
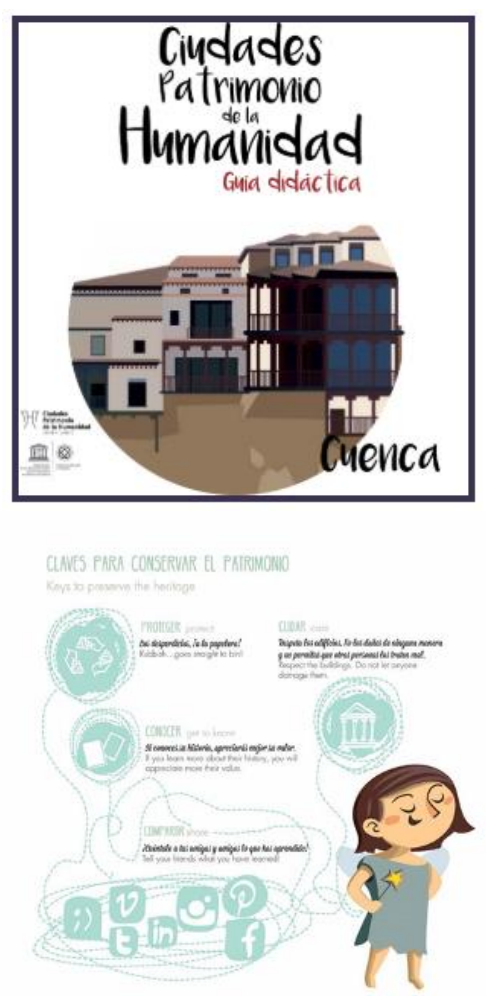

Figure 2. Publication for children on the city of Cuenca.

\section{METHODOLOGY AND OBJECTIVES}

The objectives and methodology of the work carried out in the city of Cuenca are in keeping with the main objectives and methodology of the project.
The main idea of the project has been to work on the analysis of the inhabited vernacular architecture of different European cities with the designation of World Heritage Sites in order to:

- Identify and share the different experiences on how dwellings are inhabited and physically maintained at present;

- Define and disseminate the management processes for the site in relation to the case study buildings, constructive culture, historical evolution ...

- Bring vernacular architecture closer to the younger generations through interactive digital technologies.

- Promote and improve knowledge of cultural heritage in Europe

The 3DPast project consists of three main approaches:

D1 Inhabited vernacular architectural heritage can still be found. These inhabited dwellings are a unique legacy requiring maintenance to ensure their conservation;

D2 Historic tangible heritage in relation to historic constructive techniques and materials;

D3 Intangible heritage, that is to say, the artisans who conserve the empirical knowledge of traditional constructive techniques

Therefore, the analysis of the city of Cuenca was divided into three different levels:

- General study and urban study of the city

- Study of vernacular constructive typologies

- Study of specific constructive techniques

The different strategies and activities used for this analysis are described below.

\section{ACTIVITIES CARRIED OUT}

\subsection{Study seminar on the city of Cuenca}

In November 2017 a seminar was held in Valencia on the 3DPast project, including a visit to the city of Cuenca and an initial study by the participants in the seminar, who carried out an initial analysis of the city's current situation.

The aim of the visit was for the students to carry out a direct analysis on the case study of the city of Cuenca. During the day, we met the Consorcio of the City of Cuenca, finding out about its work in coordination of all Public Administrations with competences in heritage, culture and tourism in the city. The researchers collected a small amount of data in situ, using plans and material provided by the teachers, to later provide a brief description of the current state of the historic centre of the city and a detailed analysis on both urban and territorial scale (Figure 3 ).

Each group of students was provided with some work templates to carry out data collection individually in collaboration with the rest of groups. Firstly, the environmental context was analysed (views, geography, borders and limits, façade colours...). Urban, architectural and tourist landmarks were also analysed, along with streets, flow types, traffic intensity, areas of conflict between traffic and pedestrians. Other more detailed analyses focus on these movement flows and the meeting points of vehicles and pedestrians; urban furniture, design, materials integrated into the context, and sections of streets, building height. Finally, a study was initiated on the interventions carried out in buildings, focusing on the work carried out on roofs, cornices and elements affecting the volume of the building, as well as interventions due to the change of use of the building (Figure 4). 


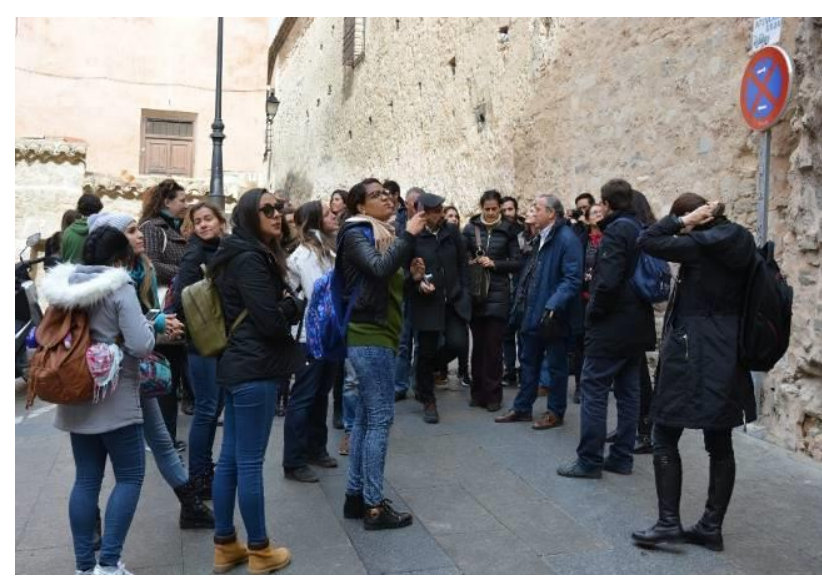

Figure 3. Participants in the session in Cuenca.
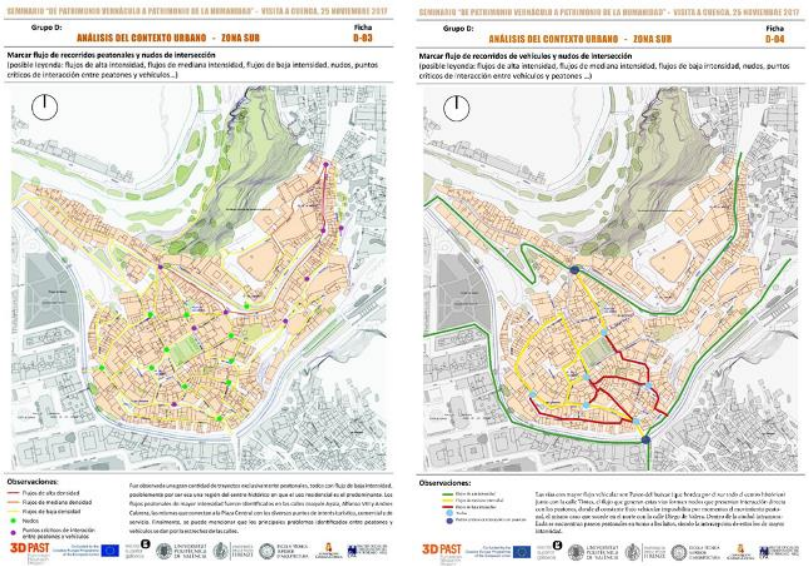

Figure 4 . In situ data collection by the students of the seminar.
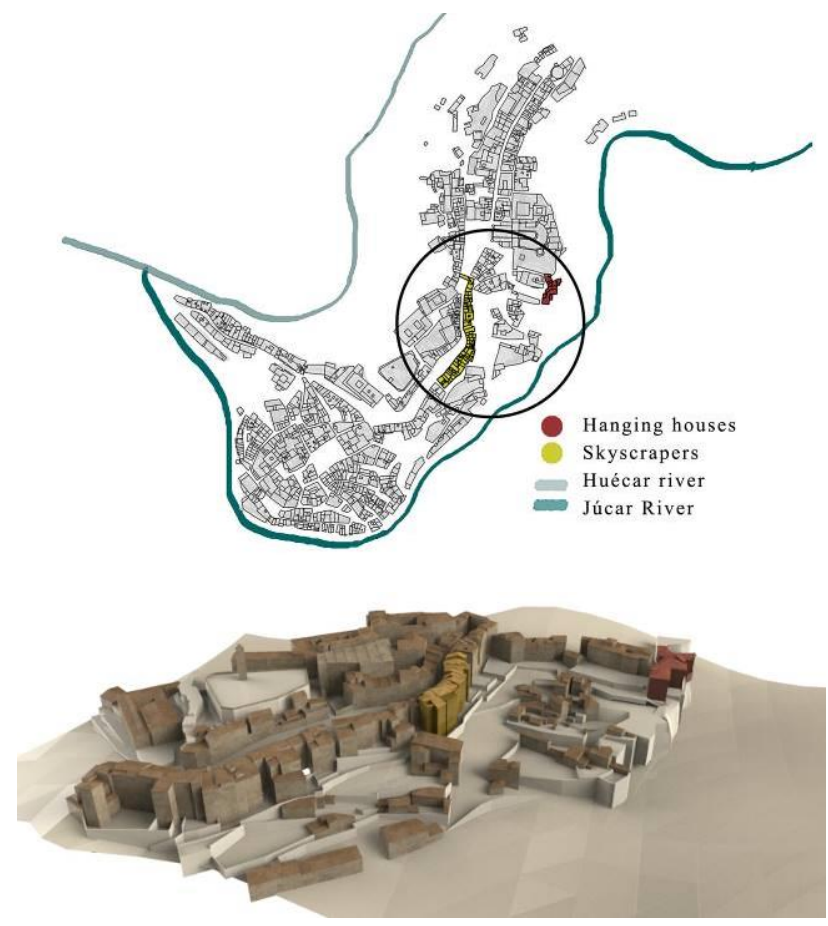

Figure 5. Location of the most representative vernacular typologies.

\subsection{D analysis of the architecture}

Furthermore, work was also carried out on a specific analysis of the traditional architecture of Cuenca, selecting the most characteristic variants.

The three most representative areas of popular architecture in Cuenca are the hanging houses (in Spanish Las casas colgadas) (red in figure 5), the houses on San Juan Street next to the Jucar River and the so-called "skyscrapers" on Alfonso VIII Street (yellow in figure 5).

This study has catalogued the different buildings in these three areas, creating a file featuring general data with location, general descriptions, description of materials and construction techniques, state of conservation, values, photographic documentation and bibliography.

\section{Rascacielos (skyscrapers)}

Because of the fortifications, there was little room to expand the city, so Cuenca residents built upwards, constructing slim, tall buildings all around the San Martín neighbourhood to cater for an increasing population. It is still not clear when these "skyscrapers" were built, but experts date them to the late Middle Ages, between the 11th and 15th centuries. This would make Cuenca's skyscrapers some of the oldest in the world. The Skyscrapers are accessed through calle Alfonso VIII, towards the Huécar gorge. Here, buildings are of uniform height and follow the line of the slope. However, on the adjacent calle Santa Catalina, which is lower than calle Alfonso VIII, they form a discontinuous conglomerate adapting to the undulating landscape and built into the cliffs themselves.

The organization of the two façades is totally different. The "main" façades on calle Alfonso VIII follow the 19th century layout that replaced the medieval irregular formation. The new façades are organized with regular and symmetrically distributed openings, ornamental elements such as balconies, mouldings, etc., and colored plaster. The façades on calle S. Catalina are characterized by irregular arrangements and extremely regular openings, a lack of plaster and decorative elements, and the presence of overhanging structure (where toilets were installed) (Figure 6).

The discontinuous conglomerate on calle Santa Catalina is composed of volumes of unusual height and a wide assortment of architectural elements in a harmonious combination of cantilevered structures, eaves with downspouts supported by wooden beams, balustrades and variety of openings. The buildings appear to be of different heights depending on the viewer's perspective (Figure 7).

Typologies and functions: "The Skyscrapers" are generally organized into very long narrow floors, they rise for several floors at street level (usually three or four) and descend behind (in some cases up to eight storeys) to find support at the foot of the escarpment or on the rough slopes. Their construction configuration is based, with exceptions, on lightweight reticulated systems of raw timber, with walls filled with adobe, rubble or brick, forming continuous "mixed" structures (Figure 8).

Originally, the interior distributions all shared the same pattern, following the prototypical scheme of the "bourgeois" medieval city: the ground floor was destined to artisan and commercial uses and the upper floors to family dwellings, although the particular disposition of these buildings determined a much 
more complex superposition of functions, using the levels below as auxiliary spaces and spaces for agricultural use. However, after the reforms of the second half of the 19th century, the subdivision of the buildings changed into a "horizontal" one, generally creating one dwelling per floor, even on the lower floors.
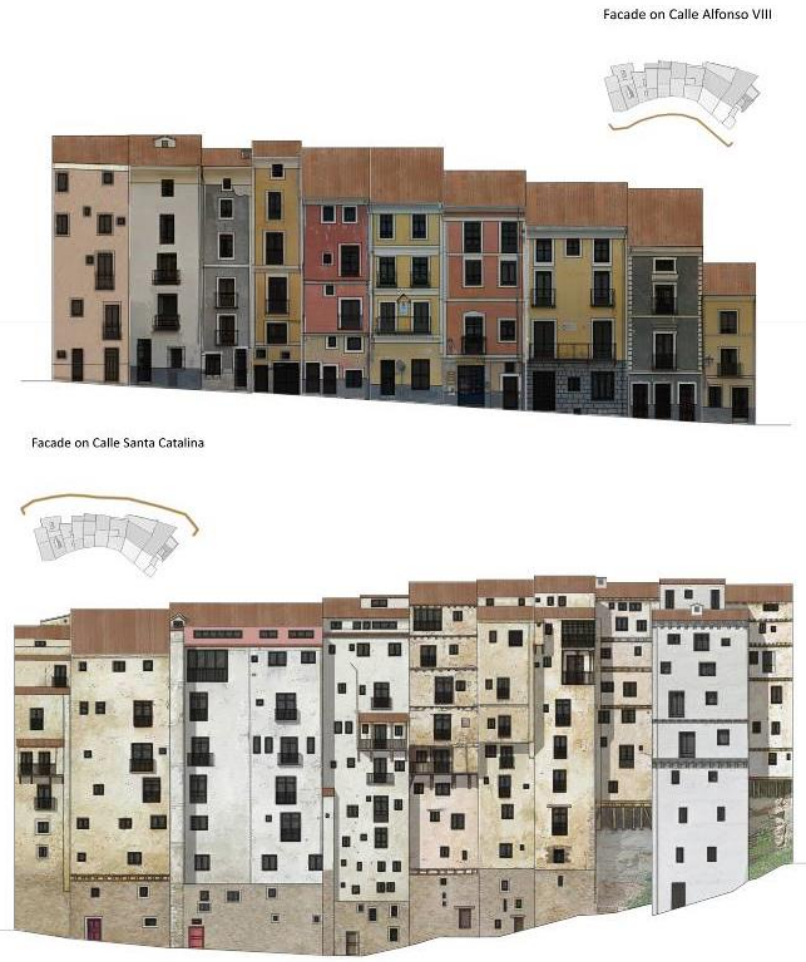

Figure 6. Façades of skyscrapers.

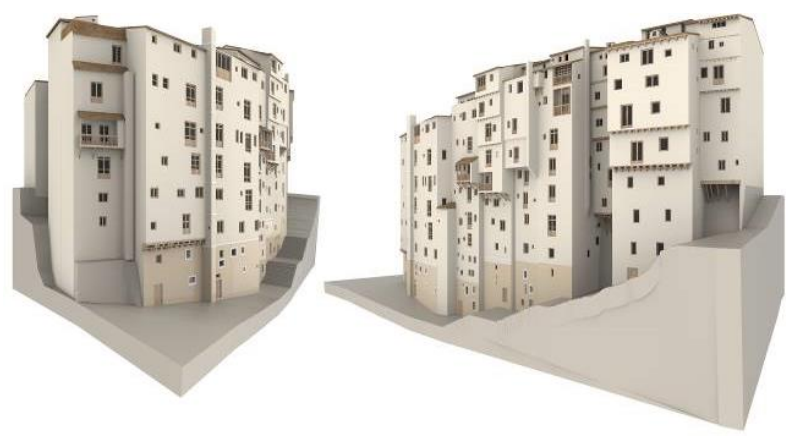

Figure 7. Skyscrapers - general 3D views.

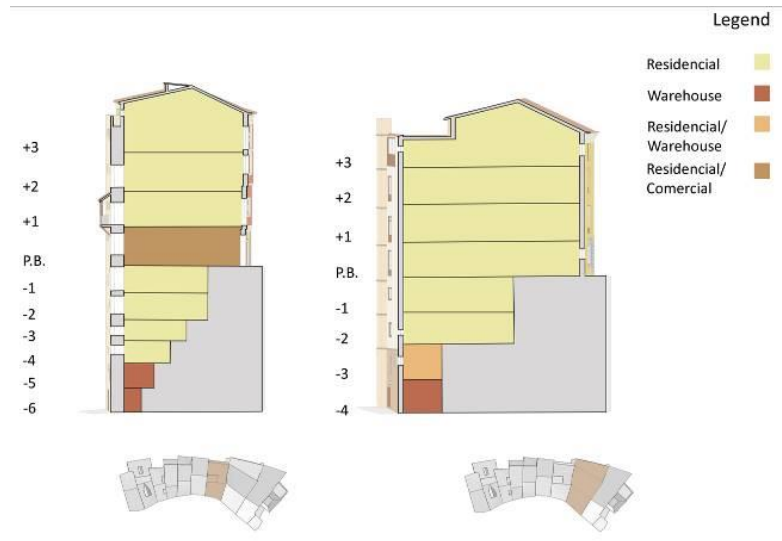

Figure 8. Analysis of typologies and functions.

\section{Casas colgadas (Hanging houses)}

Hanging Houses can be considered the most famous civil buildings in Cuenca and display the unique typology of the traditional architecture of Cuenca.

The most obvious feature of these $15^{\text {th }}$-century buildings is that they are built over a rock above the gorge of the Huécar River gorge, so that these hanging houses are the only remaining examples of a type of building so common in this city in the past.

There is extensive graphic documentation of the complex of hanging houses, made up of the house on the slope, the central house and the shields. Graphic information by E. Torrallas from 1958 has been included in an interesting book by Ibáñez Martínez edited by the University of Castilla-La Mancha and the Consorcio de la Ciudad de Cuenca. This work also includes graphic information drawn up in 1962 by Cuenca municipal architect Francisco León on the house of the slope and the central house, showing their condition prior to current transformations.

At present, the hanging houses are used for different purposes. In 1966 the central house became the Museum of Abstract Art, as the town council donated the building to the museum managed by the Juan March Foundation. Another hanging house was used as restaurant for a long time, although it is now closed.
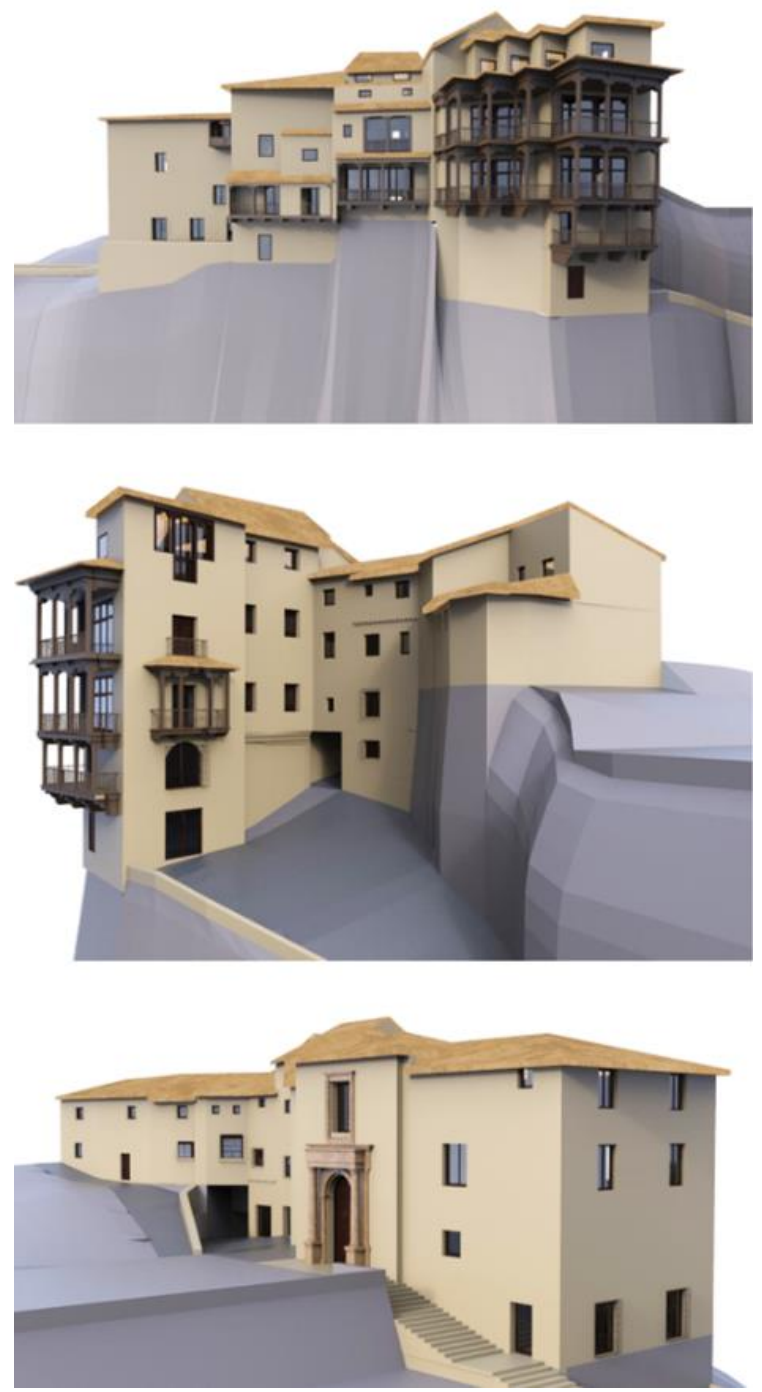

Figure 9. Hanging houses - general 3D views. 

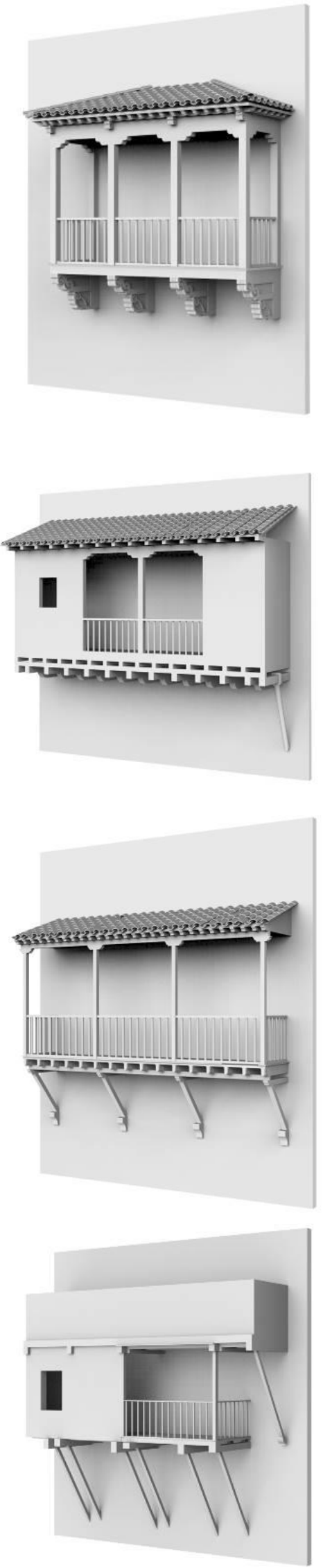

The following level of analysis studied different traditional constructive elements, such as the characteristic cantilevered elements in these buildings. For this the different balcony typologies of the overhanging houses were analysed (Figure 10). In the case of the skyscrapers more complex cantilevered structures were analysed, including the wooden strut structures generated by the overhangs of the buildings supported directly on the rock.

\section{CONCLUSIONS}

Following this study a series of conservation strategies characteristic of the management being carried out in the city of Cuenca were observed, particularly the creation of the Consorcio of the city (along with the networked collaboration of different Spanish cities with the designation of World Heritage Sites). The work of this organization and group of cities has included specific studies and publication on the heritage of these cities. In addition, specific urban planning initiatives have been analysed which take into account the preservation of the vernacular residential fabric of the city. Specific grant programmes have been set up to assist owners with the maintenance of these dwellings. Another major task being carried out is that of studying and promoting the city's heritage, with actions such as the recording of a documentary celebrating the 20th anniversary of its designation as a world heritage site or the development of interactive apps for tourist visits.

\section{ACKNOWLEDGEMENTS}

The 3D drawings of the traditional architecture of Cuenca were made by Lara Chisari and Beatrice Rossi during an Erasmus+ stay in Valencia between 11/03/2019 and 10/09/2019.

\section{NOTE}

This work has been carried out as part of the project 3D Past Living and virtual visiting world heritage site (2016-1740/001001).

\section{REFERENCES}

Ibáñez Martínez, P.M., 2016. Las Casas Colgadas y el Museo de Arte Abstracto Español. Cuenca: Ediciones de la Universidad de Castilla-La Mancha y Consorcio de la Ciudad de Cuenca.

Mondéjar Jiménez, J. A., Gómez Borja, M. A. 2009. Turismo cultural en ciudades Patrimonio de la Humanidad. Cuenca: Universidad de Castilla La Mancha.

Troitiño Vinuesa, M. A.. 1996. Arquitecturas de Cuenca 2, 2. Toledo: Servicio de Publicaciones de la Junta de Comunidades de Castilla-La Mancha.

Vicent, M., Torres, R. 1997. Cuenca: ciudad patrimonio de la Humanidad de España. Segovia: Artec.

http://www.consorciodecuenca.es/ [Retrieved 4 February 2019].

http://www.ciudadespatrimonio.org/ [Retrieved 4 February 2019].

https://whc.unesco.org/es/list/781 [Retrieved 4 February 2019].

Figure 10. 3D study of different balcony variants. 